\title{
Manuel Costa-Iscar y el anarquismo individualista en Buenos Aires
}

\author{
Manuel Costa-Iscar and individualist anarchism in Buenos Aires
}

\author{
Sebastián Stavisky*
}

Resumen: El artículo analiza el modo de practicar y difundir el anarquismo individualista por parte de Manuel Costa-Iscar, militante español que arriba a Buenos Aires en los primeros años de la década del '20. El trabajo tiene un doble propósito: avanzar en la lectura y análisis del corpus textual del autor asumiendo como perspectiva los aportes de Foucault acerca de las tecnologías del yo; discutir con ciertos modos cristalizados por la historiografía en la consideración del anarquismo individualista en Argentina.

Palabras clave: Anarquismo, Ética de sí, Individualismo, Subjetivación

\begin{abstract}
The article analyzes the way of practicing and spreading the individualist anarchism by Manuel Costa-Iscar, a Spanish activist who arrive to Buenos Aires in the early years of the 1920s. The work has a double purpose: to advance in the reading and analysis of the textual corpus of the author, assuming as perspective the Foucault's contributions about the technologies of the self; to discuss with certain crystallized ways in which the historiography considers individualist anarchism in Argentina.
\end{abstract}

Keywords: Anarchism, Ethics of the self, Individualism, Subjectivation

Recibido: 14 marzo 2019 Aceptado: 28 abril 2019

\section{Introducción}

Lejos de tratarse el anarquismo de un sistema ideológico coherente, unificado y homogéneo, existe en su interior una multiplicidad de corrientes que conviven en tensión y cuyo desarrollo va tomando forma a través del intercambio de ideas y la controversia. Dos de las tendencias que, en la Buenos Aires de fines del siglo XIX y primeras décadas del XX, transitan de manera sostenida el camino de la polémica son el individualismo y la propensión a la organización. Sin embargo, y aunque, en ocasiones, la historiografía las considere como dos vertientes de contornos más o menos definidos, incluso dentro de cada una de éstas es preciso distinguir variaciones que complejizan el heterogéneo campo de las ideas, prácticas y saberes libertarios. Dentro de lo que comúnmente se conoce como individualismo, pueden encontrarse posicionamientos diversos que van de la anti-organización a la práctica y difusión de atentados, pasando por formas de ejercicio de la militancia entendida como una reflexión permanente

\footnotetext{
* Argentino. Doctorando en Ciencias Sociales. Magister en Antropología Social. Licenciado en Sociología. IIGGUBA/CONICET. sebastian.stavisky@gmail.com
} 
en torno a las propias conductas y su posible transformación en un sentido anárquico. De igual forma, al interior de la tendencia organizacionista, podría hacerse mención de corrientes colectivistas, comunistas, sindicalistas, pro-bolcheviques, entre varias otras. Por otra parte, y a pesar de que, a lo largo de la historia, cada militante haya optado, siempre de manera situada y muchas veces variable, por referenciarse dentro de una u otra corriente -lo que, más que una elección de carácter estrictamente ideológico, remite a una toma de posicionamiento ético, a la participación en la trama de unas particulares afinidades, a la realización de unas determinadas prácticas y la difusión de unos determinados saberes-, la tensión entre un cierto individualismo y lo que Álvarez Junco llama un "comunitarismo socialista" acompaña la propia formación del anarquismo en tanto teoría política. ${ }^{1}$

A partir de estas consideraciones preliminares, en el presente artículo buscaré describir y analizar el modo particular de practicar y difundir el anarquismo individualista por parte de un militante español que arriba a Buenos Aires en los primeros años de la década del '20: Manuel Costa-Iscar. El trabajo tiene un doble propósito: por un lado, avanzar en la lectura y análisis del corpus textual de un autor que ensaya y difunde el individualismo libertario en tanto práctica reflexiva y transformadora de sus propias formas de vida; por el otro, discutir con ciertos modos cristalizados por la historiografía en la consideración del anarquismo individualista en Argentina.

En relación al segundo propósito -al cual estará dedicada la primera parte del artículo-, retomo la propuesta de revisión crítica del sentido común historiográfico del movimiento anarquista argentino realizada por Agustín Nieto, particularmente, la identificación que éste encuentra suele realizarse del anarquismo como ideología arcaica cuyo período de inscripción en la escena pública se limitaría a los años que van desde finales del siglo XIX a comienzos de la década de $1930 .{ }^{2}$ Por mi parte, considero que esta caracterización bien puede trasladarse al modo en que la historiografía concibe, desde una visión progresiva y etapista, al anarquismo individualista como lo arcaico de lo arcaico: un modo infantil e irreflexivo de practicar la militancia que, en el mejor de los casos, no se extiende más allá de 1902, y que, cuando la historiografía atiende a expresiones del individualismo en períodos posteriores -como ser la década '20, sobre la cual trata este trabajo-, no lo hace sino que a través de una identificación de éstas con la violencia, produciendo un ocultamiento de la existencia de sensibilidades anarcoindividualistas menos espectaculares y estruendosas. Sin embargo, en relación a la lectura de Nieto, cabe señalar que no acuerdo en que la visión etapista de la historia del anarquismo sea, de manera exclusiva, tributaria de una narrativa socialdemócrata. Más bien -tal como intentaré demostrar-, ella es, de alguna manera, efecto del desenlace de las polémicas entre individualistas y organizacionistas que tuvieron lugar en Buenos Aires durante el período de entresiglos, y del modo en que los segundos construyeron una particular narrativa histórica acerca de las mismas que luego sería retomada, sin demasiados miramientos, por historiadores de la academia y otros ámbitos.

La parte segunda y más extensa del artículo estará destinada, por completo, al trabajo con los escritos de Costa-Iscar. A tales fines, asumo, como perspectiva analítica, un abordaje teórico que considero oportuno para el examen del tipo de militancia desplegada por aquel: los aportes en torno a la historia de las formas de subjetivación moral realizados por Michel Foucault durante los últimos años de su vida -a los que me referiré más adelante. Dicho apartado, por un lado, retomará una serie de críticas esbozadas por Costa-Iscar tanto a la sociedad de su tiempo como a dos figuras emblemáticas del ideario anarquista: el mártir y el revolucionario; por el otro, y a partir de estas tomas de distancia, el trabajo abordará el modo en que el autor concibe lo que llama una ética de realización individual a partir de un conjunto de prácticas inherentes a tres ámbitos de la vida: la auto-educación como forma de relación con la verdad, el amor libre y las prácticas sexo-afectivas, y el cuidado naturista de la salud. De

1 Álvarez Junco, José, “Los dos anarquismos”, Cuadernos de Ruedo Ibérico, segunda época, n 55-57, enero-junio de 1977, pp. 139-156.

2 Nieto, Agustín, "Notas críticas en torno al sentido común historiográfico sobre 'el anarquismo argentino", A Contracorriente, vol. $7, \mathrm{n}^{\circ} 3$, primavera de 2010, pp. 219-248 
esta manera, el artículo buscará dar cuenta de una forma de ensayar y difundir el anarco-individualismo en Buenos Aires que, por un lado, no se circunscribe a los primeros años del anarquismo en la región, lo cual me permite romper con la idea de que tal tendencia del movimiento libertario se habría limitado a los momentos iniciáticos del mismo; por el otro, romper, también, con la asociación cristalizada entre individualismo y violencia.

\section{El anarquismo individualista en la historiografía}

\subsection{Primeras aproximaciones a la historia del individualismo}

Uno de los primeros ensayos de reconstrucción histórica del anarquismo individualista en Buenos Aires es producto, precisamente, de uno de los difusores de tales formas de la propaganda libertaria durante la última década del siglo XIX. Me refiero al andaluz José Reguera, colaborador y editor junto a su padre Manuel de, tal vez, las dos principales publicaciones anarco-individualistas de la región: El Perseguido (1890-1896) y El Rebelde (1898-1903). Inspirado por la lectura de los "Apuntes históricos" publicados en el Almanaque de La Protesta de 1909, Reguera asume la tarea de hacer memoria histórica enlazando su propia biografía a la historia del movimiento del que forma parte. El escrito, que se publica en tres partes entre el 21 y el 23 de enero de aquel año, traza una línea de tiempo que marcará con insistencia la interpretación que, posteriormente, se realizará de estos primeros años del anarquismo en el país: "De 'El Perseguido' a 'LA PROTESTA"'. Reguera refiere a la década de 1890 como un período en que "la propaganda se cubría con sus primeros pañales", y en el que la tarea de los militantes anarquistas que la llevaron a cabo se definía por la abnegación y el compromiso desinteresado. ${ }^{3}$ A partir de allí, es posible leer una doble diferenciación que el autor traza respecto al presente desde el cual escribe: por un lado, se trataría éste de un momento más maduro y consolidado de la propaganda libertaria; al mismo tiempo, de un período en el que los "sportistas, snobistas o simplemente anti políticos" cosechan para beneficio propio los frutos que él, su padre y otros compañeros de idea supieron cultivar años atrás a fuerza de sacrificio. ${ }^{4}$ De esta forma, puede decirse que la secuencia histórica -que, yendo de El Perseguido a La Protesta, va también de la preeminencia de las expresiones individualistas a la consolidación de las organizaciones al interior del anarquismo- no responde por completo a una concepción progresiva de la historia del movimiento. Reguera comprende que es necesario contar su propia experiencia para que los lectores, sintiéndose influenciados por ella, ensayen un retorno a formas desinteresadas de ejercicio de la propaganda.

Antes de volver a aquellos años alrededor de 1910 en que, como es sabido, se produce uno de los primeros clivajes en la historia del movimiento libertario en Argentina, me permito realizar un salto a 1922. En el Suplemento Semanal de La Protesta del 20 de noviembre de ese año, el militante anarquista de origen gallego José María Acha aprovecha el ensayo de un esbozo de historia del anarquismo para cargar tintas de manera polémica contra otras corrientes de la izquierda, como el socialismo y el

\footnotetext{
${ }^{3}$ Reguera, José, “De 'El Perseguido’ a 'LA PROTESTA”, La Protesta, Buenos Aires, 21 de enero de 1909, p. 1. Cabe señalar que, en 1901, Pascual Guaglianone publica un artículo en La Protesta Humana en el que ya hace referencia a la historia de algunas de las experiencias individualistas de los últimos años del siglo XIX, a las que hace responsable de la falta de inserción del anarquismo en el país. El escrito se encuentra cargado de anatemas contra los "charlatanes y microcéfalos", "discípulos de Nietzchen" (sic), dueños de "un vocabulario de palabras obscenas, de insolencias y groserías". No es mi intención determinar si puede o no considerarse este documento - cuyo autor reniega de la historia y proclama la necesidad de que el anarquismo haga tabula rasa y comience de nuevo- como un escrito de carácter historiográfico. Sin embargo, considero importante su referencia en tanto anticipa, de algún modo, algunos de los argumentos descalificativos que, más tarde, otros militantes utilizarán para arremeter contra la propaganda individualista de la época. Guaglianone, Pascual, "La propaganda anarquista en la Argentina", La Protesta Humana, 9 de marzo de 1901, p. 3-4. Más allá de la pregunta acerca del carácter historiográfico de éste u otros escritos,

${ }^{4}$ Reguera, José, “De 'El Perseguido’ a 'LA PROTESTA”, La Protesta, Buenos Aires, 23 de enero de 1909, p. 1
} 
sindicalismo, y otras tendencias del anarquismo distintas a las que él profesa, como el individualismo difundido a comienzos del siglo XX por Reguera. En su artículo, el autor contrapone la experiencia de los obreros panaderos que organizaron hacia finales de la década de 1880 la primera sociedad de resistencia en el país al "anarquismo viejo, representado por un anciano [que] alentaba en su espíritu, ya que no en su pluma, pues era de cultura deficiente, las páginas de 'El Rebelde”'. Sin dejar de lado los calificativos que presentan a Reguera como la encarnación de una forma vetusta del anarquismo a la que -a diferencia de lo interpretado por este último- nada sugeriría que fuera preciso volver, el propio Acha reconoce, no sin cierto dejo de arrepentimiento, haberse sentido inspirado, años atrás, por el "anciano esforzado [...] decrépito físicamente". Sin embargo, según el autor, la historia misma se habría encargado de demostrar el rotundo fracaso de las teorías individualistas que Reguera sostenía y que pretendidos intelectuales continuaron como forma de "entretenimiento filosófico". 5

Varios años más tarde, hacia comienzos de la década de 1950, Acha vuelve a referirse a las trayectorias de Manuel y José Reguera en sus Memorias de un anarquista publicadas en el periódico Solidaridad de la Federación Obrera Regional Uruguaya. ${ }^{6}$ En esta ocasión, sin necesidad de recurrir a los epítetos agraviantes de su anterior escrito, el autor comprende las formas de la propaganda difundidas desde El Rebelde a partir del origen de sus editores: la provincia española de Andalucía, cuyos campesinos contaban con sobradas experiencias de levantamiento espontáneo como el de 1892 en la localidad Jerez. Por otra parte, trazando una sutil pero prudente diferencia con su escrito precedente, en sus Memorias... Acha sostiene que es un error considerar individualistas a los Reguera. "E $E] 1$ individualismo sólo tenía muy aisladas manifestaciones, a través del intelectualismo plebeyo, representado por elementos que habían adquirido en los medios anarquistas nociones reflejas de ilustración y se fueron con su escepticismo a otra parte..." No era éste el caso de los editores y colaboradores de El Perseguido y El Rebelde, quienes, más que profesar un elogio deliberado a la figura del individuo, dedicaron sus esfuerzos a impugnar toda forma de organización por considerarla contraria al principio anti-autoritario del anarquismo.

Esta misma diferencia entre un anarquismo individualista y otro anti-organizador es señalada varios años antes que Acha por Eduardo Gilimón en sus Hechos y comentarios de 1911. Quien supo ser uno de los principales propagandistas del anarquismo organizador y editor de La Protesta durante gran parte de la primera década del siglo XX, dedica los capítulos que abren su libro a dar cuenta de las experiencias de militancia de los primeros anarquistas en Argentina durante la década de 1890. Para ello, recurre al método del diálogo ficcional a modo -tal señala Martín Albornoz en el prólogo que acompaña la reedición de 2011- de ilustrar la importancia que otorga al debate doctrinal como forma de templar el carácter, resaltar las diferencias y robustecer las ideas. ${ }^{8}$ Asimismo, considero que la ficción le permite también tratar aquellas primeras experiencias de militancia individualista y anti-organizadora manteniendo una distancia a través de la cual formular una crítica no exenta de ciertos dejos de ironía.

Las voces que intervienen en el diálogo pertenecen, en primera instancia, a trabajadores que se encuentran por primera vez con el periódico El Perseguido y comparten su lectura; luego, a propagandistas que lo distribuyen. Entre otras expresiones que dan cuenta del modo en que Gilimón comprende la publicación, uno de los personajes refiere que quienes escriben en ella expresan una "doctrina grandiosa", aunque con un "lenguaje grosero y a través de una sintaxis de analfabetos". 9

5 Acha, José María, "El camino andado. Esbozo histórico-doctrinario", La Protesta. Suplemento Semanal. 20 de noviembre de 1922, pp. 7-8.

${ }^{6}$ Son publicadas a lo largo de siete números entre marzo de 1951 y enero de 1954. Para el presente trabajo, tomo la edición realizada por la Biblioteca Anarquista del Cerro con introducción y notas de Pascual Muñoz.

7 Acha, José María, Memorias de un anarquista, Biblioteca Anarquista del Cerro, Montevideo, s/f, p. 25.

8 Albornoz, Martín, "Eduardo Gilimón y la obsesión por la propaganda", Gilimón, Eduardo, Hechos y comentarios. Y otros escritos: el anarquismo en Buenos Aires: 1890-1910, Buenos Aires, Terramar, 2011, p. 9.

${ }_{9}^{9}$ Gilimón, Eduardo, Hechos y comentarios. Y otros escritos: el anarquismo en Buenos Aires: 1890-1910, Buenos Aires, Terramar, 2011, p. 29-30. 
Luego, entre los repartidores del periódico, la discusión gira en torno al problema de la moral y los alcances de la libertad individual. Sin embargo, más adelante, Gilimón sostiene que el principal debate que marcó los inicios del movimiento libertario en Argentina no contaba entre sus filas con individualistas amorales, sino que en él participaban organizadores y anti-organizadores. Mientras los primeros se dedicaron a promover la asociación de trabajadores en sociedades de resistencia, los segundos creían que, en éstas, "los anarquistas se anulaban, perdían su carácter de tales y concluían por desentenderse de todo lo que tuviera atingencia con el ideal, para preocuparse tan sólo de las luchas gremiales..."10 Ahora bien, aunque Gilimón acuerda que fueron los organizadores quienes acabaron por imponerse, no por ello deja de destacar - dando cuenta de la importancia antes señalada que otorga al debate de ideas- la labor de los anti-organizadores, sin cuyo acicate posiblemente hubiera sucedido lo que ellos presagiaban. "No consiguieron, es cierto, imponer su modo de ver, pero obligaron con su tenaz campaña a los organizadores a conservar dentro de los gremios obreros fuertemente marcada su filiación y tendencia anarquista." 11

Finalmente, para cerrar este primer sub-apartado de la historiografía del anarquismo individualista y anti-organizador, me centraré en uno de los trabajos de principios de la década del '30 de Diego Abad de Santillán. Resulta éste, por supuesto, un caso particular con respecto a los autores hasta ahora referidos. En primera instancia, es quien consagra mayores esfuerzos en reconstruir de un modo sistemático la historia del anarquismo en Argentina. Por otra parte, los años en que produce sus escritos le permiten contar con una perspectiva temporal amplia capaz de trazar una periodización larga de la historia del movimiento libertario. Es por ello que resulta significativo el hecho de que, al referirse al individualismo, lo reduzca exclusivamente a las experiencias ensayadas en los últimos años del siglo XIX y primeros del XX. De esta forma, Abad de Santillán echa un manto de sombra sobre otras expresiones posteriores que no por minoritarias dejan de tener presencia en la prensa ácrata local. Al mismo tiempo, sienta las bases para la posterior consolidación de una visión progresiva del anarquismo que coloca a la tendencia individualista y anti-organizadora en una suerte de etapa primitiva o arcaica del movimiento que habría sido definitivamente superada.

En su libro El movimiento anarquista en la Argentina, Abad de Santillán otorga una importancia destacada a la experiencia de El Perseguido, cuyo período de publicación, entre 1890 e inicios de 1897, recorta un capítulo aparte en el recorrido histórico que traza. ${ }^{12}$ Según argumenta, la práctica de la espontaneidad que se difundía desde sus páginas habría marcado dicha etapa del movimiento, cuyo carácter saliente -en palabras del autor- fue "la acometividad, el entusiasmo, la fiebre proselitista, que no dejaba de retroceder ante ningún sacrificio". ${ }^{13}$ Entre otras publicaciones a las que refiere se encuentra La Liberté, dirigida por el francés Pierre Quiroule, cuya tendencia -sostiene Abad de Santillán- habría representado una corriente más teórica que la de Reguera y compañía, "que era más bien de batalla y no tenía el sentido de la organización y de la cohesión”. ${ }^{14}$

10 Ibid., p. 44. En relación a los pocos individualistas que por entonces había, Gilimón refiere que éstos no sólo cuestionaban el método de la organización, también las ideas comunistas de los anti-organizadores.

11 Ibid., pp. 43-44.

12 Abad de Santillán, Diego, El movimiento anarquista en la Argentina, Buenos Aires, Editorial Argonauta, 1930. En 1927, el autor publica un artículo en el Suplemento Quincenal de La Protesta en el que ensaya una primera lectura de este mismo período, prestándole mayor atención a la trayectoria de Francisco Denambride -colaborador de El Perseguido- y al periódico La Liberté. Abad de Santillán, Diego, "El anarquismo en la Argentina. Algunos datos sobre el período de 1890 a 1897", La Protesta. Suplemento Quincenal, Buenos Aires, 30 de marzo de 1927, pp. 66-67. Un año más tarde, publica también el artículo "El período de El Perseguido (1890-1896)", La Protesta, Buenos Aires, 10 de octubre de 1928.

13 Abad de Santillán, Diego, El movimiento anarquista..., op. cit., p. 46

14 Ibid., 52. Resulta cuanto menos llamativa esta apreciación, siendo que el segundo grupo editor de El Perseguido, de nombre La Expropiación, es responsable, por esos mismos años, de la publicación de varios folletos de importantes teóricos libertarios, así como del que Max Nettlau considera uno de los dos primeros libros anarquistas en América: La conquista del pan, de Piotr Kropotkin. Algunos de los folletos se encuentran reeditados en Folletos anarquistas en Buenos Aires: publicaciones de los grupos La Questione Sociale y La Expropiación, Buenos Aires, Biblioteca Nacional, 2015. Lucas Domínguez refiere a este momento de la historia que comienza con la edición de El Perseguido y culmina con la conformación de la Federación Obrera Argentina 
Esta serie de características atribuidas por Abad de Santillán -y, antes que él, por otros propagandistas de la organización - a El Perseguido y otros periódicos afines a su tendencia se presenta como el motivo que habría conducido a las experiencias individualistas y anti-organizadoras a su previsible fracaso. Acometividad, escasa formación teórica, escritura grosera, mala sintaxis, entusiasmo febril, analfabetismo: expresiones que se sostienen sobre una concepción etapista de las formas de la militancia que marcan los primeros años del anarquismo en la región como preludio primitivo a la madurez que el movimiento pronto comenzaría a alcanzar. Desde la perspectiva de Abad de Santillán, el florecimiento de las organizaciones libertarias se habría precipitado con el arribo al país de José Prat en 1897 y de Pietro Gori en 1898, años que el autor interpreta como un momento de transición en la historia del movimiento, durante el cual se crea la primera Federación de grupos anarquistas en oposición a individualistas y anti-organizadores. La rápida influencia de los recién llegados, junto a la militancia que ya venían desarrollando Juan Creaghe, Gregorio Inglán Lafarga y Antonio Pellicer Paraire, entre otros, habría permitido que el anarquismo en Argentina se afianzara en la tendencia organizadora, dejando definitivamente atrás la infancia arcaica del individualismo irreflexivo.

\subsection{Consolidación de una interpretación etapista}

No existen aún trabajos académicos que aborden, de manera sistemática, la historia del anarquismo individualista en Argentina como, para el caso español, por ejemplo, se cuenta con el de Xavier Diez. ${ }^{15}$ Por tanto, la trayectoria del individualismo debe ser rastreada en estudios que toman por objeto al movimiento libertario en su conjunto, en los que el primero aparece como un capítulo o apartado de una historia que lo comprende -en el sentido de que lo abarca, pero también de que pareciera explicarlo-, y suele ser referenciado a modo de contrapunto menor en relación a la hegemonía que alcanza en el país la tendencia proclive a la organización. La interpretación que estos trabajos -respecto a los cuales, dado el objeto del artículo, me centraré en los más canónicos- realizan del individualismo no es sustancialmente distinta a la sostenida por las narraciones de militantes sobre las que traté recién. Puede afirmarse, en tal sentido, que la hegemonía alcanzada por la propaganda organizadora no se reduce, solamente, al plano de las luchas históricas, sino que también se extiende al modo en que las mismas son posteriormente reconstruidas por la historiografía. Si, para Gilimón, el debate es un modo por el cual resaltar las diferencias, los desencuentros entre individualistas y organizadores son interpretados, por el contrario, como una disputa que, hasta cierto punto, acabaría homogeneizando las formas de la militancia libertaria -O, en el lenguaje de la dialéctica, como el recorrido en espiral por el que un particular, la propaganda pro-organización, habría alcanzado la categoría de universal.

Uno de los primeros trabajos en reproducir este esquema interpretativo es El anarquismo y el movimiento obrero en Argentina de Iaccov Oved. ${ }^{16}$ En él, su autor refiere a la discusión entre los anarcocomunistas anti-organizadores nucleados en torno a El Perseguido, y los anarco-socialistas o colectivistas que encuentran en los migrantes italianos del barrio de La Boca su primera y más insistente expresión. Si bien Oved realiza un pequeño comentario acerca de la afirmación de los grupos de afinidad que el referido periódico sostiene como táctica inmediata de lucha, la oposición a todo intento de organización presente en su línea editorial es el principal elemento con que caracteriza dicha experiencia. De este modo, es el lugar que ocupan las prácticas organizadoras aún no consolidadas la

en 1901, cuando las colecciones de folletos se vuelven discontinuas, como un período de auge de las prácticas editoriales anarquistas en Argentina. Domínguez, Lucas, "Un itinerario por los proyectos editoriales del anarquismo en Argentina: cambios, maniobras y permanencias", Izquierdas, 33, mayo 2017, pp. 21-41.

15 Diez, Xavier, El anarquismo individualista en España (1923-1938), Barcelona, Virus Editorial, 2007.

16 Oved, Iaacov, El anarquismo y el movimiento obrero en Argentina, México, Siglo XXI Editores, 1978. Antes que Oved, Hugo del Campo ya sostiene una concepción etapista del anarquismo al referir, entre otras expresiones, que "fue el auge del sindicalismo anarquista lo que desde comienzos del siglo eclipsó totalmente a las tendencias antiorganizadoras". Campo, Hugo del, Los anarquistas, Buenos Aires, Centro Editor de América Latina, 1971, p. 73. 
posición desde la cual lee en retrospectiva El Perseguido como una "tendencia disgregadora", portadora de una "actitud negativa" sin caracteres positivos capaces de definir su diferencia específica. ${ }^{17}$

Similar perspectiva asume el autor al momento de analizar las controversias que, por aquellos años, enfrentan a anarquistas y socialistas. Mientras estos últimos -nos dice Oved-son quienes toman la iniciativa de organizar a los trabajadores, los editores de El Perseguido serían los responsables de hacer fracasar toda posible cooperación entre militantes de ambas corrientes de izquierda. A pesar de que dicha cooperación termina, de todos modos, viéndose frustrada apenas las sociedades de resistencia anarquista logran hacerse con el control de la Federación Obrera en su segundo congreso, el autor cree pertinente señalar el error de Jacinto Oddone cuando afirma que "[f]ue el anarquismo la primera fuerza enemiga que se cruzó en el camino del movimiento socialista y obrero, obstaculizando y perturbando la obra de las sociedades gremiales y agrupaciones políticas". 18 Oved le responde entonces a Oddone que éste "no distingue entre las corrientes que ya existían en el anarquismo", y que era injusto "con los círculos pro-organización": desde su punto de vista, la responsabilidad del fracaso de la cooperación entre socialistas y anarquistas le cabe por completo a los editores de El Perseguido. ${ }^{19}$

La referida insistencia en el carácter puramente negativo de quienes optan por formas de la militancia distintas a la participación en organizaciones más o menos duraderas se encuentra también en el trabajo de Gonzalo Zaragoza sobre el anarquismo en Argentina. ${ }^{20}$ Así como Oved refiere a los primeros años de la década de 1890 como una etapa disgregadora del movimiento anarquista, Zaragoza hace referencia a ella como el período de la "dispersión individualista". Algunas de las características que marcarían dicha etapa son -según el autor- la atomización y la desconexión, y las prácticas de los individualistas a las que recurre para fundamentar la responsabilidad que éstos tendrían en el carácter dispersivo del anarquismo de su época son la defensa de las ideas de insurrección espontánea y de propaganda por el hecho, la interrupción de reuniones destinadas a promover la asociación de trabajadores, y la negación a trazar diferencia alguna entre socialistas y anarquistas organizadores. A diferencia de Abad de Santillán, Zaragoza sostiene que el período de transición entre la etapa individualista del anarquismo y aquella que le sigue se produce entre 1895 y 1897, marcando este último año el momento en que "la causa de la organización ha triunfado". ${ }^{21}$ De esta forma, individualistas y organizadores se presentan, antes que como diferentes expresiones irreductibles una a la otra, como dos bandos enfrentados en que la victoria de uno habría marcado la derrota y consecuente desaparición del otro.

También reproducen esta misma gramática trabajos posteriores que se inscriben dentro de los estudios culturales del anarquismo en el país. Tal es el caso de Juan Suriano, quien, si bien refiere al movimiento anarquista del período de entresiglos como "un verdadero caos doctrinal" en el que las distintas tendencias libertarias "se identificaban y se rechazaban en el heterogéneo y variado mosaico del anarquismo porteño", no deja de señalar a individualistas y anti-organizadores de la década de 1890 como figuras de un obstáculo que el movimiento debió sortear para alcanzar su expansión y consolidación en el contexto local. ${ }^{22} \mathrm{El}$ individualismo constituye -para el autor- "un problema para la difusión relativamente coherente del mensaje doctrinario", al mismo tiempo que "una traba para la

\footnotetext{
${ }_{17}$ Oved, Iaacov, op. cit., México, Siglo XXI Editores, 1978, p. 47 y 48.

18 Oddone, Jacinto, Historia del socialismo argentino, Tomo I, p. 161, citado en Oved, Iaacov, op. cit., p. 53. Sobre las controversias entre socialistas y anarquistas en la década de 1890, ver Albornoz, Martín, "Los encuentros de controversia entre anarquistas y socialistas (1890-1902)", Bruno, Paula (Dir.), Sociabilidades y vida cultural. Buenos Aires, 1860-1930, Buenos Aires, Universidad de Quilmes, 2014, pp. 187-218.

19 Oved, Iaacov, op. cit., p. 53.

20 Zaragoza Ruvira, Gonzalo, Anarquismo argentino (1876-1902), Madrid, Ediciones de la Torre, 1996.

${ }^{21}$ Ibid., p. 116. Más adelante, Zaragoza afirma que, para 1908, “П]os grupos individualistas pierden importancia”. Ibid., p. 233. Esta concepción etapista del anarquismo se encuentra también presente en un artículo previo del mismo autor: Zaragoza Ruvira, Gonzalo “Aproximación al anarquismo americano: el caso argentino”, Estudios: Revista de bistoria moderna, n 5, 1976, pp. 173-185.

22 Suriano, Juan, Anarquistas: cultura y politica libertaria en Buenos Aires, 1890-1910, Buenos Aires, Manantial, 2008, p. 77.
} 
expansión de las prácticas sociales". ${ }^{23}$ Habiéndose encerrado en sí mismo y constituyéndose en mero reproductor de los debates europeos, el anarquismo que antecede a la proliferación de las sociedades de resistencia de los primeros años del siglo XX habría sido incapaz de lograr su inserción no tan sólo entre los sectores trabajadores, sino incluso en el conjunto de la sociedad argentina. ${ }^{24} \mathrm{~A}$ través de una sutil diferencia con otros autores, Suriano refiere que la definitiva consolidación de la tendencia organizadora se habría producido tras la huelga general y sanción de la Ley de Residencia de 1902, luego de la cual, al poco tiempo, el periódico El Rebelde deja de salir. "A partir de este conflicto el movimiento anarquista adquirió cierta madurez y un peso relativo en la escena política y social urbana de la Argentina, del que saldría ampliamente favorecida la tendencia organizadora..." 25 -sostiene el autor a través de una interpretación progresiva del devenir libertario (deudora, recordemos, de la narrativa de Abad de Santillán) que ya anticipa en la introducción del libro, cuando refiere a las experiencias del novecientos como las de un "anarquismo maduro" en relación con aquel que le precede. ${ }^{26}$

Otro de los temas al que los historiadores del anarquismo refieren con insistencia al momento de caracterizar esta etapa del movimiento es el problema de la violencia. Como vimos, varios militantes anarquistas aluden a ella como una característica propia del lenguaje de los periódicos individualistas. Pero el tema de la violencia aparece, también-en este caso con cierta preferencia por parte de la historiografía académica-, como objeto de debate en torno a los atentados que por aquellos años tienen lugar en Europa. Sin intención de detenerme en el tratamiento específico de los discursos anarquistas sobre el tema -lo que excede el objeto de este trabajo ${ }^{27}$, , me interesa señalar dos cuestiones. Por un lado, que el relativo silencio acerca de los debates en torno a los atentados por parte de los historiadores militantes en relación con los académicos tal vez se deba a que, sin desconocer las particularidades que tiene el asunto hacia finales del siglo XIX, el problema de la violencia, lejos de ser exclusivo de una determinada época, acompaña al anarquismo a lo largo de gran parte de su historia, y las posiciones que se sostienen frente a él no son tan fácilmente asignables, de manera exclusiva, a una u otra tendencia. Por el otro, así como -tal es analizado, entre otros, por Zaragoza ${ }^{28}$ - la prensa comercial construye una imagen del anarquismo asociado al terror que no necesariamente se corresponde con las formas de la militancia de los propios anarquistas, podría decirse que cierta historiografía hace lo propio entre individualismo y violencia. Me refiero, en este caso, ya no tanto a los estudios sobre las experiencias del período que hasta acá vengo tratando, sino a algunos de los trabajos de Osvaldo Bayer sobre la década de 1920: su obra dedicada a la vida y muerte de Severino Di Giovanni, y el artículo que presta título al libro Los anarquistas expropiadores.

Mientras Gilimón y Acha creen oportuno señalar el error de considerar a los integrantes de El Perseguido y El Rebelde como individualistas, siendo que sus prácticas y discursos mejor debieran ser caracterizados como anti-organizadores, los trabajos de Bayer producen un aplanamiento de la imagen del individualismo que no distingue los diferentes modos en que el mismo se expresa. Pasando por alto la inexistencia de atentados anarquistas en Argentina durante la década de 1890, en su libro dedicado al antifascista italiano traza una línea de continuidad entre la propaganda de aquellos años y la difundida hacia mediados de los años veinte por Di Giovanni. Así lo refiere cuando sostiene que "[e]l anarquismo individualista, que había tenido gran impulso a fines de siglo, volvió a renacer con la publicación de 'Culmine' de Severino Di Giovanni”. ${ }^{29}$ Cabe precisar, al respecto, que lo que para el autor caracteriza el

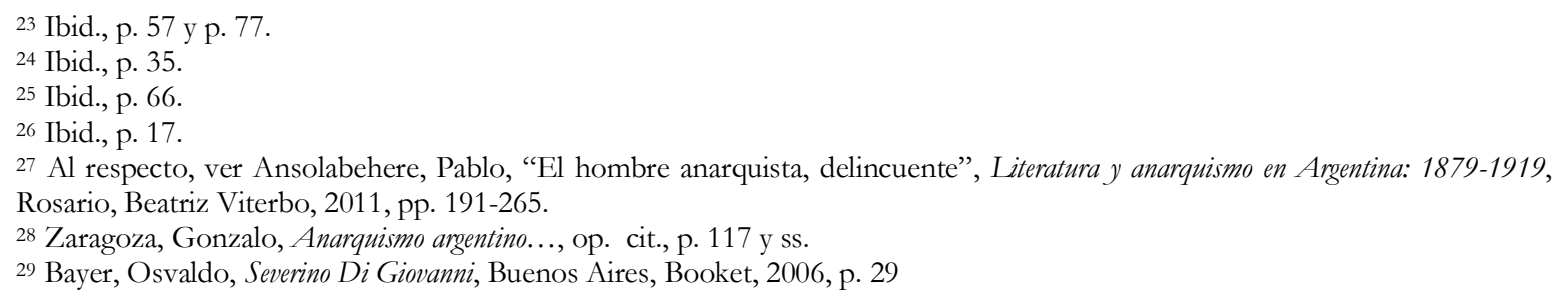


individualismo de Di Giovanni y su publicación no es más que la opción por los atentados violentos como instancia privilegiada de lucha contra el régimen social, táctica a la que -a lo largo del libro- Bayer opone las formas de la militancia ligadas a la organización de la que considera el "ala moderada" del anarquismo representada por La Protesta y la Federación Obrera Regional Argentina.

Aunque, en este caso, es la perspectiva de la propaganda que se expresa renuente a la organización la que asume el autor, los trabajos Bayer acaban también presentando al anarquismo como un campo de tensiones dicotómicas que impide reconocer las ambigüedades propias de una corriente de ideas atravesada no por una contradicción, sino por múltiples diferencias. Tal vez, las páginas del libro citado que mejor expresen este reduccionismo sean aquellas que componen el capítulo titulado "Anarcobanditismo contra anarquismo de salón". ${ }^{30}$ Ahora bien, no sólo en su trabajo sobre el antifascista italiano Bayer opone la comodidad en la que supuestamente se habrían resguardado los anarquistas organizadores a la violencia que ejecutan y, al mismo tiempo, se exponen los individualistas, sino también en su libro Los anarquistas expropiadores. Allí, el autor afirma que, "mientras los intelectuales anarquistas siguen discutiendo entre sí la forma en que se desarrollará la vida cuando no haya más gobiernos, los anarco-individualistas aplican la acción directa y queman tranvías o hacen saltar panaderías por el aire..."31 Por un lado, entonces, anarquistas organizadores e intelectuales opuestos sin más a individualistas; por el otro, anarquistas individualistas y no intelectuales asociados sin más a la violencia. Tales son las imágenes con que la narrativa de Bayer simplifica la complejidad de las diversas formas de la propaganda que marcan el anarquismo de la década del '20.

Para finalizar, cabe señalar el trabajo de Luciana Anapios, una de las pocas investigadoras que se ha dedicado al estudio pormenorizado del anarquismo en Argentina durante el período de entreguerras. En uno de sus artículos, la autora trata de manera específica el problema de la violencia, la propaganda por el hecho y los debates producidos al respecto en la prensa anarquista entre fines de la década del veinte y comienzos de la del treinta. Lejos de la búsqueda por dividir el campo de las diferencias entre libertarios en dos bandos enfrentados, al mismo tiempo que tomando distancia de la asociación entre anarquismo y violencia a cuya naturalización -como bien señala- colaboran los trabajos de Bayer, Anapios se propone comprender algunas de las diversas posiciones asumidas en torno a los atentados. Como hipótesis, señala la posibilidad de encontrar un punto de inflexión en la ejecución de la condena a muerte de Sacco y Vanzetti, hecho que marca el cierre de las manifestaciones populares en reclamo de justicia por los dos trabajadores italianos radicados en Estados Unidos. ${ }^{32}$ Desde esta perspectiva, es posible comprender no tan sólo la existencia en el anarquismo de diferentes modos de concebir la violencia -los cuales, por otra parte, no se condicen, necesariamente, con la

\footnotetext{
30 Bayer, Osvaldo, "Anarcobanditismo contra anarquismo de salón”, Ibid., pp. 121-143. A propósito del libro de Bayer y, particularmente, de este capítulo, Martín Albornoz realiza un oportuno análisis que procura comprenderlo a partir del contexto de la lucha armada de los años setenta en que el trabajo fue inicialmente publicado. Albornoz, Martín, "Los atentados anarquistas", Tonkonoff, Sergio et. al., Violencia y cultura: reflexiones contemporáneas sobre Argentina, Buenos Aires, CLACSO, 2014, pp. 31-47.

31 Bayer, Osvaldo, Los anarquistas expropiadores, Buenos Aires, Booket, 2008, pp. 9 y 11. Cabe precisar, al respecto, que la imaginación acerca de la forma que asumiría la vida futura no fue una práctica demasiado difundida en el anarquismo local, tal como lo constatan las discusiones que en distintos momentos se produjeron entre espontaneístas, renuentes a la creación tanto de programas como de utopías, y constructivistas. Al respecto, puede consultarse el apartado "Ciudad anarquista" en Ansolabehere, Pablo, op. cit., pp. 269-276.

32 Anapios, Luciana, 'La ciudad de las bombas. El anarquismo y la 'propaganda por el hecho' en la Buenos Aires de los años veinte", Boletin del Instituto de Historia Argentina y Americana "Dr. Emilio Ravignani", Tercera serie, $\mathrm{n}^{\circ}$ 39, segundo semestre de 2013, pp. 42-75. Sobre las movilizaciones por Sacco y Vanzetti, ver Suriano, Juan y Anapios, Luciana, "Anarquistas en las calles de Buenos Aires (1890-1930)", Lobato, Mirta Zaida (editora), Buenos Aires: manifestaciones, fiestas y rituales en el siglo XX, Buenos Aires, Biblos, 2011, pp. 77-100. Dada la importancia del período estudiado por Anapios para lo que sigue del presente artículo, cabe destacar, también, Anapios, Luciana, "Prensa y estrategias editoriales del movimiento anarquista en la Argentina de entreguerras", Anuario del Instituto de Historia Argentina, 16(2), e025, 2016. Disponible en: http://www.anuarioiha.fahce.unlp.edu.ar/article/view/IHAe025. Consultado el 1 de marzo de 1919
} 
división entre organizadores e individualistas-, sino también su variación en el tiempo según la relación que la ejecución de atentados pueda tener con los procesos de movilización colectiva.

\section{El anarquismo individualista de Manuel Costa-Iscar}

\subsection{Apuntes biográficos y perspectiva analítica}

A partir de este recorrido por las maneras de concebir el anarquismo individualista por parte de la historiografía, pasaré ahora a analizar la propaganda difundida por Manuel Costa-Iscar. Al respecto, me centraré, específicamente, en escritos suyos publicados durante la década del '20 y primeros años del '30 en Buenos Aires, aunque tomaré también como referencia publicaciones anteriores del periódico Tierra y Libertad de Barcelona. Con tales fines, buscaré prestar conformidad del devenir de un pensamiento que no se restringe a un período histórico preciso ni a un contexto geográfico con límites prefijados, sino que se despliega a lo largo del tiempo y de modo transnacional, poniendo en conexión puntos distantes intersectados por un recorrido biográfico singular. Asimismo -tal como señalé en la introducción de este trabajo-, el presente apartado buscará brindar testimonio de una sensibilidad histórica en la práctica del anarco-individualismo que, por una parte, excede el estricto recorte temporal al que la historiografía relega dichas formas de la militancia; por la otra, me permite poner en cuestión la asociación cristalizada entre individualismo y violencia.

Manuel Costa-Iscar es el seudónimo utilizado (en ocasiones sin enguionar) por Antonio Faciabén, militante anarquista nacido en 1883 en la región de Navarra, España. En su país natal y a partir de la década de 1910, forma parte de distintos grupos de afinidad y colabora con diversas publicaciones libertarias: Tierra y Libertad, Estudios, La Revista Blanca, Al Margen, entre otras. En la primera de ellas, publica, a modo de folletín entre los meses de febrero y abril de 1913, el escrito Impresiones de un viaje a pie por Francia y España, y, hacia 1916, integra su grupo editor, año en que también publica el libro Generalidades educativas. Traduce escritos de autores franceses vinculados al anarquismo individualista, como Émile Armand y Han Ryner, con quienes mantiene intercambios epistolares. Algunas de las principales obras traducidas son El anarquismo individualista, del primero, y Pequeño manual individualista y La sabiduría riente, del segundo, además de un libro sobre sexualidad del Dr. L. Breselle, Lo que todos deberían saber. La iniciación sexual. En 1920, viaja a Brasil junto a su pareja, Juliette Hart, para recalar tres años más tarde en Buenos Aires, donde transcurre el resto de su vida. En esta última ciudad, escribe artículos para distintas publicaciones libertarias: La Antorcha, La Protesta y su Suplemento Semanal, Superación y la revista Nervio - de la que forma parte de su grupo editor-, además de colaborar en otras publicaciones del campo de las izquierdas, como Claridad. El 13 de mayo de 1923 dicta una conferencia de controversia en el local de la Sociedad de Panaderos con el título de "El naturismo y el problema humano", la cual luego es publicada bajo el nombre de Crítica y concepto libertario del naturismo por la editorial Bautista Fueyo. Otros libros suyos son: ¿Qué ocurre en el mundo? Causas y efectos de la guerra, a través de Ediciones La Idea Libre (sin fecha, circa 1940), y La enseñanza laica ante la racionalista, publicado en 1966 - presunto año de su muerte- por la editorial Tierra y Libertad de México. ${ }^{33}$

Gran parte de los artículos, libros y conferencias de Costa-Iscar giran en torno a temas relacionados con la ética y el modo a través del cual considera que cada quien podrá alcanzar su realización individual desde una perspectiva libertaria. El campo de aplicación del trabajo que propone al individuo realizar consigo mismo -y que él mismo ensaya consigo- abarca un abanico temático heterogéneo: prácticas de amor libre, del cuidado naturista de la salud, de auto-educación, reflexiones acerca del pacifismo, el feminismo, y -cruzando de manera transversal al conjunto- indagaciones sobre

33 Algunos de los datos biográficos fueron tomados de Iñíguez, Miguel, Esbozo de una enciclopedia histórica del anarquismo español, Madrid, Fundación de Estudios Libertarios Anselmo Lorenzo, 2001. Otros, en su mayor parte, son el resultado de la propia investigación. 
la importancia de discernir entre las necesidades naturales y prioritarias de la existencia, y los placeres impuestos por una sociedad a la que califica de artificiosa. De esta forma, es posible leer la propaganda anarco-individualista de Costa-Iscar como una suerte de manual práctico y libertario de tecnologias del yo o, mejor, del uno mismo, en el sentido en que éstas son teorizadas por Michel Foucault durante los últimos años de su vida. ${ }^{34}$

Como se sabe, los libros, conferencias y cursos del filósofo francés dedicados al estudio de lo que -en su volumen titulado El uso de los placeres- dio en llamar una "historia de las formas de la subjetivación moral y de las prácticas de sî" 35 toman, principalmente, como objeto de análisis los ejercicios espirituales de la antigua Grecia, el período helenista y primeros años del cristianismo. Sin embargo, no por ello deja de señalar, en reiteradas ocasiones, la posibilidad de extender su perspectiva analítica para el estudio de otras experiencias históricas como, por otra parte, realizan múltiples investigadores que se sirven de sus desarrollos. ${ }^{36}$ Ahora bien, en relación al anarquismo, es el propio Foucault quien manifiesta, cuanto menos en tres ocasiones, la importancia de emprender una indagación que lo tome por objeto a partir de la perspectiva por él mismo desplegada.

La primera alusión aparece en el primer curso dedicado explícitamente a las formas históricas de subjetivación a partir del vínculo que, en el cristianismo antiguo, el sujeto es llamado a entablar con la verdad. Allí sugiere que es posible comprender el principio epistemológico de la no existencia de "una legitimidad intrínseca del poder" como un método de carácter anarquista, tras lo cual propone que -dada la definición en ocasiones atribuida al anarquismo acerca del poder como un fenómeno esencialmente malo y capaz, en algún futuro, de ser superado por completo- mejor sería hablar, ensayando un juego de palabras, de una anarqueología. ${ }^{77}$ Luego, en su artículo "El sujeto y el poder", Foucault sostiene que el estudio del poder debiera ser indagado a través no de su racionalidad interna, sino del conjunto de luchas que ofrecen resistencia a los efectos que éste produce allí mismo donde se desencadenan. Se trata de luchas transversales e inmediatas contra las políticas identitarias y los privilegios del saber, para las cuales sugiere el nombre de "luchas anarquistas". 38 Finalmente, en el último de sus cursos dictados en el Collège de France, el filósofo francés refiere que la relación ética que el individuo entabla con la verdad en la búsqueda de subjetivarse a sí mismo -y cuya figura paradigmática rastrea en los cínicos- es posible encontrarla en ciertas experiencias de la militancia como forma de vida revolucionaria, entre las que, nuevamente, hace alusión al anarquismo. Al respecto, retomo de estas experiencias la idea de militancia como "estilo de existencia" que busca "romper con

\footnotetext{
34 Me refiero, de manera particular, a los tomos II y III de su Historia de la sexualidad, y a la larga lista de cursos, conferencias y entrevistas que comienza a dar, de manera aproximada, a partir de 1978. Sobre la diferencia entre el concepto del yo y del uno mismo, ver Morey, Miguel, "Introducción”, Foucault, Michel, Tecnologías del yo, Buenos Aires, Paidós, 2008, pp. 9-44.

${ }_{35}$ Foucault, Michel, Historia de la sexualidad II. El uso de los placeres, Trad. Solet Martí, Buenos Aires, Siglo XXI, 2011, p. 35.

36 En relación al estudio de la cultura anarquista en Argentina, algunos trabajos que echan mano a la perspectiva foucaulteana son: Ferrer, Christian, “Átomos sueltos. El 'cuidado de sí' entre los anarquistas a comienzos del siglo XX”, en Abraham, Tomás (comp.), El último Foucault, Buenos Aires, Sudamericana, 2003, p. 239-262; Di Stefano, Mariana, "Capítulo III. La lectura y la escritura como tecnologías del yo", en El lector libertario: prácticas e ideologías lectoras del anarquismo argentino: 1898-1915, Buenos Aires, Eudeba, 2013, pp. 83-104; Stavisky, Sebastián, "Médicos de sí mismos. Medicina naturista, revolución social y éxodo de la ciudad en el anarquismo de Buenos Aires a comienzos del siglo XX", ecopolitica, $\mathrm{n}^{\circ}$ 16, septiembre-diciembre de 2016, pp. 2-25.

37 Foucault, Michel, Del gobierno de los vivos: Curso en el Collège de France: 1979-1980, Trad. Horacio Pons, Buenos Aires: FCE, 2014, p. 99-100.

${ }^{38}$ Foucault, Michel. "El sujeto y el poder", Trad. Rogelio C. Paredes, Dreyfus, Hubert L. y Rabinow, Paul, Michel Foucault: más allá del estructuralismo y la hermenéutica, Buenos Aires, Nueva Visión, 2001, pp. 241-259. A propósito de este artículo, y del modo en que es posible pensar la propuesta ética foucaulteana como la búsqueda por constituir un sujeto anárquico, ver Schürmann, Reiner, "De la constitución de uno mismo como sujeto anárquico", Traducción de Alan Cruz e Ilya Semo Bechet, Fractal, no 75, enero-abril de 2015. Disponible en:

https://www.mxfractal.org/articulos/RevistaFractal75ReinerSchurmann.php?fbclid=IwAR0VQS2SBYiubWSBYiubWWgT5B YeSdG_hUpFxRy9TiL4VqlBuB-cjitxvo. Consultado el 6 de marzo de 2019.
} 
las convenciones, los hábitos, los valores de la sociedad". ${ }^{39}$ Se trata de una experiencia que hace de la propia vida la manifestación de otra vida posible, considerada ésta como la "verdadera vida" que, en cuanto tal, pone en cuestión las formas establecidas de la existencia frente a las cuales se manifiesta. Es decir, un modo por el cual la ética de sí se constituye en una crítica de los imperativos sociales o, si se prefiere, un momento en que la crítica a tales imperativos se articula de modo inmanente a una instancia de constitución ética del sujeto. ${ }^{40}$

Tomando estas rápidas consideraciones -sobre las que volveré hacia el final del artículo, aunque su desarrollo en profundidad excede el objeto de este trabajo- como punto de apoyo para el análisis, pasaré a continuación a referirme por entero a la propaganda anarco-individualista difundida y ensayada por Costa-Iscar. A tales fines -y como señalé más arriba-, organizaré la argumentación en dos sub-apartados: el primero estará dedicado a la crítica esbozada por el autor tanto a la sociedad de su tiempo como a ciertas figuras emblemáticas del anarquismo; el segundo, a su ética de realización individual por medio de una serie de prácticas que se inscriben en tres ámbitos de la vida: la auto-educación como forma de relación con la verdad, el amor libre y las relaciones sexo-afectivas, y el cuidado naturista de la salud.

\subsection{Crítica de los imperativos sociales}

Una de las principales críticas realizadas por Costa-Iscar a la sociedad en que vive remite a lo que considera la artificialidad de una civilización que habría producido un desvío en el ser humano de su condición originaria y de las leyes naturales en que la misma se inscribe. Se trata de un tema que -como referí antes- atraviesa gran parte de su obra, y que tiene sus fundamentos en una concepción anarquista de la naturaleza como estado armónico de carácter mítico-utópico que resulta tributaria de la filosofía materialista del siglo XVIII. ${ }^{41}$ Sin embargo, más allá de las características propias de la ideología libertaria, cabría situar estas consideraciones en el contexto histórico y geográfico en que las mismas tienen lugar para el caso que acá nos atañe. Me refiero, específicamente, al contexto de modernización periférica por el que atraviesa la ciudad de Buenos Aires de los años '20 y '30, durante el cual comienzan a tomar forma una cultura y un consumo de masas que cuenta, entre sus fenómenos más resonantes, con el despegue de la industria automotriz, la difusión de la radio y el cine, y la aparición de una prensa moderna cuyo principal exponente es el diario Crítica. ${ }^{42}$

Estas aclaraciones no implican, necesariamente, que Costa-Iscar haga en sus escritos explícita referencia y manifieste un definido rechazo a los hábitos y costumbres que caracterizan las transformaciones en las formas de vida durante el período de entre-guerras. Sin embargo, no por ello sería prudente desestimar el entramado cultural del que sus reflexiones se recortan y del que busca tomar distancia por medio de un conjunto de prácticas destinadas a darse a sí mismo una conducta de carácter libertaria. Por otra parte, la crítica a lo que él llama la civilización artificial posee -al igual que la

\footnotetext{
${ }^{39}$ Foucault, Michel, El coraje de la verdad: el gobierno de sí y de los otros II. Curso en el College de France (1983-1984), Traducción de Horacio Pons, Buenos Aires, Fondo de Cultura Económica, 2010, pp. 196-197.

40 Acerca del modo en que en el pensamiento foucaulteano se articulan las instancias crítica y ética, ver Chignola, Sandro, "El coraje de la verdad. Parresía y crítica", Foucault más allá de Foucault: una política de la filosofía, Trad. Fernando Venturi, Buenos Aires, Cactus, 2018, pp. 199-231. Por mi parte, abordé la relación entre crítica y ética en Foucault en diálogo con los desarrollos de Max Stirner -filósofo alemán de mediados del siglo XIX cuyo pensamiento fue bien recibido y ampliamente difundido por anarquistas individualistas-, en Stavisky, Sebastián, "Crítica al humanismo y ética de sí en Foucault y Stirner", Revista de Humanidades, en prensa.

${ }_{41} \mathrm{Al}$ respecto, ver Álvarez Junco, José, La ideología politica del anarquismo español (1868-1910), Madrid, Siglo XXI de España Editores, 1976; Girón Sierra, Álvaro, En la mesa con Darwin. Evolución y revolución en el movimiento libertario en España (1869-1914), Madrid, Consejo Superior de Investigaciones Científicas, 2005.

${ }_{42}$ Existe una amplia bibliografía sobre el tema. Entre otros, puede consultarse: Sarlo, Beatriz, Una modernidad periférica: Buenos Aires 1920-1930, Buenos Aires, Nueva Visión, 2003; Saítta, Sylvia, Regueros de tinta. El diario Crítica en la década de 1920, Buenos Aires, Sudamerica, 1998; Karush, Matthew B., Cultura de clase. Radio y cine en la creación de una Argentina dividida (1920-1946), Buenos Aires, Ariel, 2013.
} 
idea de naturaleza por la que se define en oposición- un contenido más bien vago que varía según la reflexión a la que esté abocado. Así -como veremos más adelante-, cuando trate sobre la autoeducación, referirá a los espiritualismos religiosos; cuando lo haga sobre el amor libre, al matrimonio; cuando lo haga sobre el naturismo y la alimentación frugívora, a las mixtificaciones de una cocina emplazada por la gula. Finalmente, cabe señalar que, en su gran mayoría, las intervenciones de CostaIscar en la prensa están dirigidas a sus propios compañeros de idea, con quienes busca polemizar, aunque no siempre sus señalamientos obtengan resonancia.

El primero de los escritos de Costa-Iscar en la prensa ácrata de Buenos Aires aparece en el periódico La Antorcha del 13 de mayo de 1921, y es escrito antes de su arribo al país mientras aún se encuentra en Brasil. En él describe las sensaciones que le dejó su viaje en barco desde Europa, durante el cual compartió travesía con emigrados en quienes percibió "gestos viles", "efectos deprimentes", y "un hedor más repugnante que el que se nota entre el ganado". Es entonces que se pregunta: "¿cómo mejorar las relaciones humanas sin que paralelamente se perfeccione cada uno por sí mismo?" La respuesta la encuentra en el retorno del ser humano a las leyes de la naturaleza y su devenir armónico por medio de un culto a la vida sencilla dispuesta a quitarse de encima la artificialidad de esa "roña incrustada por una educación malsana". ${ }^{43}$ En este caso, sí obtiene una respuesta por parte de los editores del periódico, quienes, sintiéndose interpelados por el autor de la nota, argumentan que, entre esa misma masa de explotados cuyas formas tanto le repugnan, se encuentran muchos obreros conscientes que aspiran a una "humanidad más perfeccionada, que el camarada Costa-Iscar no nos sabría negar, sin negarnos a nosotros mismos". ${ }^{44}$

Pero las críticas que Costa-Iscar profiere no se limitan a señalar los malos hábitos de las multitudes, sino que también se dirigen hacia figuras emblemáticas del ideario ácrata. Me refiero, particularmente, a las figuras del mártir y el revolucionario, contra las cuales desarrolla argumentos que buscan iluminar los elementos de carácter cristiano que ambas comportan. ${ }^{45}$ Respecto a la primera, escribe una serie de artículos mientras aún se encuentra en Barcelona, en los que argumenta que la admiración religiosa al martirio se fundamenta en la sujeción de los seres humanos por falsos idealismos que les hacen olvidar las necesidades vitales de cuidado de su propio cuerpo. A distancia de las exaltaciones de una entrega absoluta de sí, afirma la necesidad de luchar contra el sistema de opresión asumiendo una actitud de prudencia que permita reconocer los instantes de peligro a los fines no de lanzarse sobre ellos, sino de procurar evitarlos. Para esto, recomienda ensayar un "equilibrio entre las fuerzas de empuje y las de reserva", saber cuándo y cómo avanzar en el combate contra la tiranía, y cuándo y cómo resguardarse sin que implique un acto de cobardía. Este equilibrio podría alcanzarse como resultado de un trabajo de evaluación de las condiciones en que se desarrolla la lucha y, junto a ella, la propia existencia, para la cual el cuidado de la vida se erige como principio al que ni aún en las situaciones más extremas de opresión debiera renunciarse. Desde esta perspectiva, el sacrificio de los mártires es, para Costa-Iscar, no un ejemplo a seguir por el conjunto de los anarquistas, sino una experiencia cuyo recuerdo debiera estimular prudencia en los impulsivos incitándoles a "rendir culto a los lazos que les unen a la vida". ${ }^{46}$

43 Costa-Iscar, Manuel, "La bestia humana", La Antorcha, año I, nº 8, Buenos Aires, 13 de mayo de 1921.

44 “A Costa-Iscar", La Antorcha, año I, nº 8, Buenos Aires, 13 de mayo de 1921.

45 Sobre la influencia de ciertas ideas cristianas en el pensamiento anarquista, además del ya citado trabajo de Álvarez Junco, puede consultarse: Joll, James, Los anarquistas, Barcelona, Ediciones Grijalbo, 1968; Litvak, Lily, Musa libertaria: arte, literatura y vida cultural del anarquismo español (1880-1913), Madrid, Fundación de Estudios Libertarios Anselmo Lorenzo, 2001.

${ }^{46}$ Costa-Iscar, Manuel, "Después de la tragedia. Consideraciones fundamentales", Tierra y Libertad, Época 4", año VII, $\mathrm{n}^{\circ} 11$, Barcelona, 5 de mayo de 1910. Sobre el mismo tema, “Elogio a la audacia!”, Tierra y Libertad, Época 4, año IX, nº 108, 8 de mayo de 1912. Sobre la importancia de la figura del mártir en el anarquismo de Buenos Aires, ver Suriano, Juan, "Capítulo VIII. Ritos y símbolos anarquistas", op. cit., pp. 299-333; Stavisky, Sebastián, "La primera víctima del movimiento obrero. El discurso anarquista sobre la muerte en los albores del siglo XX en Argentina", Revista Conflicto Social, año 10, $\mathrm{n}^{\circ}$ 18, juliodiciembre de 2017, pp. 168-195. 
Años más tarde, ya en Buenos Aires, Costa-Iscar vuelve a poner en cuestión elementos de fuerte pregnancia en el ideario anarquista a los fines de ensayar una crítica a la figura del revolucionario, en quien encuentra la mala costumbre de una práctica adulatoria del pueblo y los resabios de la espera redentora del "mesías rojo que, tea en mano, produzca la conflagración purificadora". A diferencia del revolucionario, Costa-Iscar se posiciona a sí mismo entre los individualistas que, tomando distancia de los malos hábitos de las multitudes, quieren "llegar al máximo grado de autoeducación libertaria, perenne crítica social y realización individual". ${ }^{47}$ El revolucionario y el individualista son no sólo dos figuras arquetípicas, sino dos posicionamientos éticos y, por tanto, dos perspectivas distintas desde las cuales comprender y emprender el camino hacia la posible transformación. Esta heterogeneidad de puntos de vista, por otra parte, no se restringe a la discusión en torno a la violencia con que la historiografía suele reducir las diferencias entre individualistas y organizadores $\mathrm{o}$, en este caso, revolucionarios. La disputa remite a la relación que el individuo que se aprecie de libertario debe entablar consigo mismo y con aquellos que le rodean, tema sobre el que tratan varios de los escritos de Costa-Iscar. Entre ellos, se encuentra una serie de artículos publicados en abril de 1923 en La Protesta, a lo largo de los cuales critica duramente la política de los anarco-bolcheviques organizados en la Alianza Libertaria Argentina y proclives a la dictadura del proletariado que por esos años se desarrolla en la Unión Soviética. ${ }^{48}$ Allí afirma que la violencia no es un camino por el cual pueda alcanzarse la anarquía, y relativiza luego su rechazo a la figura del revolucionario, aunque las características con que lo define se encuentran lejos de confirmar la imagen del gran redentor.

Un revolucionario o -como también le llama Costa-Iscar- un "verdadero anarquista" es aquel que ajusta "todas sus acciones a sus palabras, inspiradas en la más libre voluntad". ${ }^{49}$ Es, también, quien busca hacerse de un carácter propio y reflexivo, el que no se deja atrapar por los cantos de sirena de los dirigentes con ansias de mando, el que se sustrae de la inercia de las multitudes, con las que se mezcla cuando éstas se lanzan a la lucha contra la tiranía y de las que vuelve a tomar distancia cuando se perfila la instauración de un nuevo orden. El verdadero anarquista o revolucionario sin concesiones es el que desobedece las disposiciones de todo gobierno, sea éste monárquico, burgués o proletario, el que busca hacerse para sí una forma de vida liberada de los códigos de convivencia establecidos, de las falsas atracciones y de los mezquinos oportunismos. Si no se quiere "declarar la bancarrota del anarquismo" sentencia Costa-Iscar-, es preciso seguir siendo "refractarios a la imposición de los de arriba y de los de abajo [...] considerándonos artistas de la existencia para concebirla en todos sus aspectos noblemente bella, viviéndola lo mejor posible, de conformidad con nuestro ideal anárquico". .50

Para la anteúltima parte de su artículo, Costa-Iscar traduce un escrito de Gérard de LacazeDuthiers publicado en el periódico anarco-individualista francés l'en dehors en el que, a los caracteres diferenciales que contornean la figura del revolucionario, añade el de un "pensamiento elevado [que] medita y sueña, sin violentar a nadie para imponer sus ideas: él mismo se violenta para reformarse, buscando hacerse mejor". Lo que de este modo se efectúa es una suerte de plegamiento sobre sí de la idea de revolución a los fines de llevar a cabo una "revolución interior" que -sostiene Costa-Iscar apoyándose en Lacaze-Duthiers-, lejos de implicar una auto-reclusión en las propias convicciones convertidas en castillo de cristal, busca afirmarse en el desinterés por la escalada de los peldaños del poder. ${ }^{51}$ Así, el tipo de individualismo que Costa-Iscar practica y profesa no es estrictamente el de un

\footnotetext{
47 Costa-Iscar, Manuel, “Apuntes sobre la independencia individual”, La Protesta. Suplemente Semanal, año 2, n ${ }^{\circ}$ 57, Buenos Aires, 19 de febrero de 1923, p. 2. Cabe precisar que el rechazo de Costa-Iscar a las prácticas de adulación hacia el pueblo radica no sólo en la distancia que establece con la figura del revolucionario, sino también en cierta postura aristocratizante que, en ocasiones -como vimos previamente-, le hace ver con desagrado las manifestaciones populares de las multitudes.

48 Sobre la historia del anarco-bolcheviquismo en Buenos Aires y de la Alianza Libertaria Argentina, ver Doeswijk, Andreas L., Los anarco-bocheviques rioplatenses 1917-1930, Buenos Aires, CeDInCI Editores, 2013.

${ }^{49}$ Costa-Iscar, Manuel, "Los anarquistas y la dictadura", La Protesta, año XXVI, n 4372, Buenos Aires, 11 de abril de 1923.

50 Costa-Iscar, Manuel, "Los anarquistas y la dictadura”, La Protesta, año XXVI, No 4373, Buenos Aires, 12 de abril de 1923.

51 Costa-Iscar, Manuel, "Los anarquistas y la dictadura”, La Protesta, año XXVI, No 4376, Buenos Aires, 15 de abril de 1923.
} 
egoísta acérrimo, sino más bien el de una voluntad dispuesta a solidarizarse con todos aquellos que expresen, también, un gesto de indocilidad ante las jerarquías. Esta importancia en las prácticas de apoyo mutuo que él mismo reivindica $-\mathrm{y}$ que muchos anarquistas organizadores niegan a los individualistas ${ }^{52}$ - se constituye en una de las instancias en que la búsqueda de realización individual se enlaza al deseo de transformación social. ${ }^{53}$ Claro que, sin embargo, no se trata de un sentimiento de solidaridad imperturbable que, una vez estrechado, se mantenga a pesar de cualquier modificación en las condiciones en que haya emergido. De modo similar a la dinámica propia de los grupos de afinidad que los anarco-individualistas de finales del siglo XIX conformaban para la realización de sus proyectos comunes, el tipo de solidaridad que practica Costa-Iscar consiste en un vínculo que requiere confirmarse en cada situación según el grado de independencia que los individuos implicados en él sean capaces de manifestar respecto a los imperativos de los que aquel considera imperioso tomar distancia.

\section{3. Ética de realización individual}

Como referí antes, el camino de la revolución interior, de la realización individual que Costa-Iscar propaga y ensaya consigo mismo, contempla diversos tipos de prácticas. A continuación, me centraré en el análisis del modo en que el autor aborda algunos puntos centrales del trabajo ético que el individuo que se considera anarquista debiera realizar en torno a tres de estos ámbitos de la vida: la auto-educación, las relaciones sexo-afectivas y la salud.

El tema de la auto-educación remite, en el pensamiento de Costa-Iscar, al tipo de relación que el sujeto que se quiere libertario debe entablar con la verdad. Tal es el objeto de una serie de artículos que el autor publica entre la segunda mitad del año 1922 y comienzos de 1923 en el Suplemento Semanal de La Protesta. ${ }^{54}$ En ellos, realiza una crítica a las concepciones de la cultura como propiedad exclusiva de las élites, y sostiene que las distinciones jerárquicas entre grados de saber son el resultado de una civilización artificial de la que es preciso sustraerse. Afirma entonces una igualación general de las potencialidades de todas las inteligencias, cuya única diferenciación resulta no de una presunta superioridad espiritual reservada a unos pocos elegidos, sino de la fuerza del pensamiento de cada uno. Como modelo filosófico de conducta, recupera la figura de Epicuro, "quien supo libertar las conciencias del temor de los dioses y distingue las necesidades naturales que hacen fuerte y feliz al hombre de todas las demás que le fuerzan a ser cobarde y servil", y proclama "la necesaria vulgarización de todo lo que se conoce, para que cada uno se asimile la parte adecuada a su capacidad y comprensión". 55

Para Costa-Iscar, la verdad no es una, sino múltiple y relativa a cada individuo, y, en cuanto tal, sólo puede alcanzarse a través del método experimental de conocimiento, que comprende como un

\footnotetext{
52 Entre varios otros, puede citarse, al respecto, un artículo en que su autor, Diego Abad de Santillán, carga tintas contras los seguidores de Han Ryner -autor que, recordemos, Costa-Iscar traduce- con anatemas que recuerdan a los utilizados para referirse a los anarco-individualistas de finales del siglo XIX. Los considera "afeminados" que sólo miran el mundo introspectivamente, castradores de "las energías viriles de muchos elementos anarquistas", sustraídos en sus propias capillas "a las demandas de una vida revolucionaria activa". Abad de Santillán, Diego, "Vidal Georges - Han Ryner, L’homme et l'oeuvre", La Protesta. Suplemento Semanal, año IV, no 174, Buenos Aires, 25 de mayo de 1925, p. 8.

53 Lector apasionado de Nietzsche -al igual que muchos otros anarco-individualistas-, en una nota publicada en 1931 en la revista Nervio, Costa-Iscar dice encontrar en el filósofo alemán "un individualismo generoso o 'altruista" del que extrae enseñanzas para su propia vida. Costa-Iscar, Manuel, "Nietzsche ante la libertad”, Nervio, año 1, n 3, Buenos Aires, Julio de 1931, p. 9-15.

${ }^{54}$ Existen varios trabajos sobre las prácticas educativas del anarquismo a comienzos del siglo XX. Entre ellos, tanto por su condición seminal como por la rigurosidad de su desarrollo, cabe remitir a Barrancos, Dora, Anarquismo, educación y costumbres en la Argentina de principios de siglo, Buenos Aires, Editorial Contrapunto, 1990. Sin embargo, resulta significativo que ni éste ni ninguno de los estudios posteriores tome en consideración las experiencias de auto-educación en el anarquismo.

55 Costa-Iscar, Manuel, "Reflexiones sobre la cultura", La Protesta. Suplemento Semanal, año I, nº 30, Buenos Aires, 7 de agosto de 1922, p. 7.
} 
modo de filosofía anarquista en oposición a la metafísica sobre la que se cimentan las relaciones de mando y obediencia. La autoridad -sostiene- es un orden impuesto por la fuerza que se mantiene por una concepción metafísica de la verdad de la que una minoría se presenta como poseedora para imponerla al resto. Por intermedio de la propia experiencia inmediata de las cosas, los espíritus libres serían capaces de rehuir el misticismo de la verdad impuesto por la fuerza y por abstracciones carentes de fundamento empírico, es decir, de ensayar una crítica a las opresiones que los sujetan y poner en cuestión la verdad de la autoridad. De esta forma, la auto-educación permitiría al individuo realizarse a sí mismo y elevarse intelectualmente. Ambos movimientos, el de la crítica al orden social y el de la constitución ética de sí, se enlazan y toman consistencia en la relación que el individuo asume con la verdad sin más intermediario que el ejercicio de su propia inteligencia. Esta forma de conocimiento es presentada por Costa-Iscar como una práctica ética y filosófica de carácter libertaria capaz de destronar las abstracciones religiosas que lo gobiernan.

El anarquismo -sostiene el autor- es "una crítica constante, extensa y profunda de la Humanidad, un medio adecuado de auto-educación, de adquirir carácter y de llegar a curarse de los efectos perniciosos del espiritualismo, que arrastra todos los errores que sufrieron nuestros antepasados". ${ }^{56}$ No se trata de una ideología que pueda seguirse como principio regulador de la propia conducta, tampoco de una organización a la cual plegarse renunciando a fragmentos de la propia voluntad, sino de una disposición ética, de un arte de la existencia -como el mismo autor refiere- que exige del individuo una atención permanente sobre sí mismo y sobre los placeres superfluos que le sujetan a un orden que le es impuesto de manera arbitraria. Rehuir de tales placeres, así como de las ficciones sobre las que se sostiene el orden social, exige un trabajo de circunspección que permita al individuo desarraigar de su fuero interno toda idea fija y avanzar, a través de su propia experiencia, en el camino de la revolución interior. "¿Te parece poco?... - pregunta Costa-Iscar hacia el final de un artículo publicado a comienzos de 1923- A nuestro juicio, en tal desarraigo consiste lo mejor de la conducta humana, que es tanto como decir libertaria." 57

Otra de las dimensiones de la vida sobre las que Costa-Iscar experimenta en su búsqueda de transformación individual como vector del cambio social remite al ámbito de las relaciones sexoafectivas. Dentro de ellas, es posible englobar un amplio repertorio temático que va del amor libre a la cuestión de la homosexualidad, del control de la natalidad a las funciones de cuidado de la infancia. Como expone Laura Fernández Cordero en su libro Amor y anarquismo, lejos de tratarse de asuntos sobre los que se haya alcanzado, al interior del pensamiento libertario, una serie de acuerdos generales de tipo doctrinario, los mismos conforman tópicos de debate que componen -como sucedió también con tantos otros temas- un concierto de voces heterogéneas. En lo que hace al repertorio de relaciones sexo-afectivas -refiere la autora-, "quizá las vertientes individualistas fueran más permeables a pensar la pluralidad de deseos y el derecho personal a disfrutarlos". ${ }^{8}$ Tal es el caso de Costa-Iscar, quien escribe al respecto varios artículos en distintas publicaciones anarquistas y del campo de las izquierdas, al tiempo que traduce obras como el ya referido libro del Dr. L. Breselle, Lo que todos deberían saber. La iniciación sexual.

Gran parte de las colaboraciones realizadas por Costa-Iscar para el periódico Tierra y Libertad de Barcelona tienen como temática principal la cuestión del amor libre. Sin embargo, por él no refiere a experiencias de amor múltiple, sino que lo restringe a la importancia, para una ética libertaria, de entablar relaciones afectivas de unión libre sin sanción legal ni religiosa, es decir, fundadas y sostenidas

\footnotetext{
56 Costa-Iscar, Manuel, "Más reflexiones sobre la cultura", La Protesta. Suplemento Semanal, año I, no 35, Buenos Aires, 11 de septiembre de 1922, p. 3.

57 Costa-Iscar, Manuel, "Definiendo el progreso", La Protesta. Suplemento Semanal, año II, no 54, Buenos Aires, 29 de enero de 1923 , p. 1.

${ }^{58}$ Fernández Cordero, Laura, Amor y anarquismo: Experiencias pioneras que pensaron y ejercieron la libertad sexual, Buenos Aires, Siglo XXI Editores, 2017, p. 135.
} 
sin más que por el mutuo acuerdo de los amantes -lo que, en su caso, como para la gran mayoría de los anarquistas de su tiempo, remite, con exclusividad, a la pareja heterosexual. Entre sus artículos, uno de los más extensos -compuesto por siete partes publicadas en números sucesivos- lleva por título, precisamente, "Hacia el amor libre", y consiste en una suerte de decálogo procedimental acerca de las actitudes que los anarquistas debieran asumir a los fines de alcanzar relaciones amorosas de tipo racional capaces de domeñar el arbitrio de las pasiones. ${ }^{59}$ Además de la importancia de no dejarse engañar por lo que llama la farsa del matrimonio, el artículo remite a cuestiones de diversa índole tales como el control neo-malthusiano de la natalidad, el cuidado de la salud, la independencia económica de la mujer (a quien, por otra parte, en caso de haber tomado voluntariamente los amantes la decisión de procreación consciente, reserva el rol de cuidado de la infancia) y el valor moral de la sencillez en la estética corporal.

Varios años más tarde, ya en Buenos Aires, Costa-Iscar retoma algunos de estos planteos en un artículo publicado en el primer número de un periódico quincenal anarquista de corta duración que lleva por título Superación. El escrito esboza una crítica a las novelas románticas en que el amor sexual es descripto como "dueño y tirano de los humanos civilizados", y desarrolla la importancia de que los espíritus iconoclastas se presten a levantar un dique de contención contra las venalidades de la carne. "La pasión sexual, y todas las pasiones, deben ser las servidoras del humano, pero no sus tiranas; desde el momento que le dominan, su voluntad se debilita, su resistencia a la sugestión decrece y lo arrastran a la decrepitud y a la muerte." 60 Costa-Iscar apuesta, entonces, por un ideal de frugalidad y auto-control en el juego recíproco de las atracciones, dentro del cual la comunión de pensamientos sinceros toma la posta de los perfumes, los cosméticos y las sedas con que -afirma- los representantes de las clases poseedoras ornamentan sus cuerpos entregados a la lascivia. Nuevamente, la razón es esgrimida como arma con la cual enfrentar el avance irreflexivo de las pasiones sexuales, pero no se trata ésta de una lucha por desprenderse de la animalidad que aún habitaría en cada ser humano, sino de un combate contra la artificialidad de una civilización que lo habría hecho alejarse del correcto sendero de las afectividades. Hacia comienzos de la década del '30, Costa-Iscar vuelve sobre estas cuestiones desde las páginas de la revista Nervio, de la que por entonces oficia como integrante de su grupo editor. Una vez más, el objeto de su crítica es el sensualismo con que la cultura artificial recubre el vínculo natural entre los amantes, "que originariamente no es más que la voluntad de las especies para reproducirse", lo que convierte las relaciones afectivas en un lodazal de vicios, crímenes y enfermedades. ${ }^{61}$ De lo que se trata es de recuperar la natural unión libre entre los seres que la civilización contaminó con sus fantasías mal comprendidas de placeres concupiscentes y su falsa moral del matrimonio. Esta tarea se vuelve tanto más urgente cuando a ella se enlaza el asunto de la reproducción que, "producto de la imprevisión y de la ceguera del instinto, [produce] vástagos tarados que perpetúan las infinitas fealdades que ensombrecen el mundo, constituyendo una carga para sí mismo y para la sociedad que debe aguantarlos..."62 Así, a la importancia del amor libre proclamada por Costa-Iscar como relación afectiva de carácter libertario se acopla, de modo inseparable, la necesidad de practicar la procreación consciente o "maternidad libre" -como le llama en otro de sus artículos en que, a diferencia de los anteriores, refiere a la posibilidad de la pluralidad amorosa. ${ }^{63}$

Finalmente, el último de los ámbitos de la vida sobre los que me propongo tratar en este artículo, y a los que la ética individualista de Costa-Iscar en tanto práctica libertaria de sí presta atención,

\footnotetext{
${ }^{59}$ Costa-Iscar, Manuel, "Hacia el amor libre", Tierra y Libertad, Época IV, Nº 204 al 210, Barcelona, 11 de marzo al 22 de abril de 1914.

${ }^{60}$ Costa-Iscar, Manuel, "El amor en la novela", Superación, Año I, N 1, Buenos Aires, 4 de julio de 1925.

${ }^{61}$ Costa Iscar, Manuel, “Algo sobre sexualismo”, Nervio, Año I, Nº 6, Buenos Aires, octubre de 1931, p. 29-31, p. 29.

62 Ibid., p. 29. Acerca de los discursos de control de la natalidad en el anarquismo de la época, ver Ledesma Prietto, Nadia, "La revolución sexual de nuestro tiempo": el discurso médico anarquista sobre el control de la natalidad, la maternidad y el placer sexual. Argentina, 1931-1951, Buenos Aires, Biblos, 2016.

${ }^{63}$ Costa-Iscar, Manuel, "La Tragedia de la Mujer en Buenos Aires", Claridad, Año XIII, Nº 279, Buenos Aires, julio de 1934.
} 
refiere al tema del cuidado naturista de la salud. La cuestión del naturismo y su relación con el anarquismo en Argentina es un tema aún casi inexplorado por la historiografía. ${ }^{64}$ Ciertamente, no son muchos los militantes libertarios que, durante las primeras décadas del siglo XX en la región, hayan expresado públicamente su rechazo al consumo de medicamentos alopáticos y el uso de vacunas, y manifestado, en su reemplazo, una voluntad de prevenir y curar las distintas enfermedades con terapias naturales tales como diversos tipos de baños de agua, caminatas al aire libre y bajo el sol, o el sostenimiento de una alimentación a base de verduras, frutas y hortalizas. Incluso, en más de una ocasión, la publicación en la prensa anarquista de escritos que afirman los beneficios de tales formas del cuidado de la salud (o, simplemente, de publicidades de libros o consultorios naturistas) resulta objeto de dura crítica por parte de quienes se erigen en custodios de los saberes de la tradicional ciencia médica. En su gran mayoría, los autores de los primeros acostumbran ser militantes identificados con la corriente anarco-individualista, dispuestos a ensayar consigo mismos una transformación en sus formas de vida, como es el caso de Costa-Iscar.

Tal como sucediera con otros de los asuntos aquí tratados, las primeras contribuciones del autor acerca del naturismo aparecen en el periódico Tierra y Libertad de Barcelona. Allí, hacia mediados de 1914, traduce del francés y publica una serie de artículos sobre "Higiene de la alimentación racional" de Eugenia Rey-Rochat de Théolier, para los cuales escribe antes una nota introductoria. Nuevamente, Costa-Iscar alude en ella al tema de la perversión producida sobre la naturaleza del ser humano por una civilización artificial, en este caso con respecto a la alimentación: “...el hombre hubiera ganado mucho si para alimentarse hubiera guardado algo de la sencillez primitiva, mas la glotonería, la gula, le han inducido a complicar [...] lo que ha dado en llamarse arte culinario". Contra estas innecesarias complicaciones de la cocina que incitan a la gula, afirma que "el ideal de la alimentación estriba en que el hombre civilizado sea capaz de ser frugívoro", práctica alimentaria por la cual anhela que cada individuo alcance a "ser el médico de sí mismo" -fórmula que opera a modo de teleología que guía las prácticas y saberes del conjunto de los naturistas, no necesariamente vinculados al campo libertario. Hacia el final de su introducción, Costa-Iscar traza un vínculo entre esta "revolución culinaria" y aquella otra revolución que anhelan sus compañeros de idea: "Y aunque esto pueda ser causa de hilaridad, razonablemente merece reflexión y estudio. ¿Qué duda cabe que por la evolución de todos los sentidos se prepara también la Revolución definitiva que dé al traste con todos los viejos atavismos?" 65

Nueve años más tarde, en Buenos Aires, Costa-Iscar retoma el tema como objeto de una conferencia titulada "El naturismo y el problema humano". Inicialmente planificada para realizarse el domingo 6 de mayo de 1923 en el local de la Liga de Educación Racionalista, el entusiasmo que despierta en la concurrencia obliga a que sea postergada al día 13, cambiando la locación a la sede de la Sociedad de Panaderos. En este caso, su optimismo respecto a los alcances de la medicina naturista se ve sensiblemente apaciguado. Así lo manifiesta en la invitación que realiza a la conferencia, donde alude a las excesivas pretensiones de la doctrina por "resolver la tan ardua y compleja cuestión humana", lo que para el autor implica un entrometimiento de la misma en cuestiones que atañen a la filosofía anarquista, la única -según su perspectiva- capaz de ofrecer una respuesta a tamaño problema. Entre

\footnotetext{
${ }^{64}$ Este tema específico constituye el objeto de mis investigaciones de doctorado que actualmente vengo realizando, y acerca del cual publiqué un artículo: Stavisky, Sebastián, "Médicos de sí mismos...”, op. cit. Para el caso español, puede consultarse: Masjuan, Eduard, "El naturismo", La ecología humana del anarquismo ibérico: urbanismo "orgánico" o ecológico, neomalthusianismo y naturismo social, Barcelona, Icaria, 2000, pp. 429-464; Roselló, Josep Maria, "El naturismo libertario (1890-1939), La vuelta a la naturaleza. El pensamiento naturista hispano (1890-2000): naturismo libertario, trofología, vegetarismo naturita, vegetarismo social y librecultura, Barcelona, Virus Editorial, 2003, pp. 137-234; Cubero Izquierdo, María Carmen, La pérdida del pudor. El naturismo libertario español (1900-1936), Madrid, LaMalatesta Editorial, 2015.

${ }^{65}$ Costa-Iscar, Manuel, "Algo sobre higiene”, Tierra y Libertad, Época IV, Nº 215, Barcelona, 27 de mayo de 1914. Un asunto que me llama la atención es no haber encontrado ninguna otra referencia a la autora que Costa-Iscar dice traducir, lo que me permite pensar que, tal vez, se trate de un escrito suyo que éste opta por dar a conocer atribuyendo su autoría a alguien más. Quizás, si así fuera, el motivo radique en la hilaridad que él mismo reconoce el tema pueda despertar entre los lectores del periódico.
} 
las razones que argumenta en contra del naturismo, refiere a su falta de coherencia. Mientras hasta hace algunos años los llamados a sí mismo profesores naturistas creían que toda dolencia podía tratarse recurriendo a distintas clases de baños, hoy es la comida la que ocupa, gracias a la influencia de la trofología, el lugar de cura universal de toda enfermedad. "'Dime lo que comes y te diré quién eres'. Esa es la nueva fórmula y, si la humanidad quiere ver la justicia, la verdad, la belleza y el bienestar sobre la tierra, que sepa sobre todo cuándo, cómo y qué debe comer" -refiere Costa-Iscar con cierta ironía, tomando prudente distancia no sólo del naturismo, sino también de sus anteriores escritos. ${ }^{66}$

$\mathrm{Al}$ parecer, y a pesar de la escasa atención prestada a los asuntos del naturismo en la prensa anarquista de Buenos Aires, la conferencia tiene muy buena repercusión en el público, y no sólo por las dimensiones de su concurrencia, sino también por una serie de comentarios favorables realizados a ella desde las páginas de La Protesta. Posiblemente, la generosa recepción se deba a que, lejos de un elogio de las prácticas y saberes de la medicina natural, la misma consistió -como, entre otros, resalta un colaborador que firma con el nombre de Pequeño Espartaco- en una sólida refutación de sus falacias, como aquella que sostiene, contra el ideal sostenido antes por el propio Costa-Iscar, que "la constitución del hombre está destinada exclusivamente al frugivorismo”. Otro de ellos, Luis Argos, solicita que, dada la importancia que para los anarquistas tiene lo esgrimido por el conferencista, su alocución sea publicada en las columnas del periódico. ${ }^{67}$ Sin embargo, esto no sucede y, finalmente, es el propio Costa-Iscar quien afronta, con sus propios medios, la publicación de su conferencia con el título de Crítica y concepto libertario del naturismo a través de la editorial Bautista Fueyo. Allí, sus cuestionamientos a los inconsecuentes principios doctrinales de la medicina naturista y, particularmente, a las regulaciones alimentarias que ésta busca imponer, se enlazan a una propuesta de naturismo libertario entendido, de manera amplia, como una reflexión permanente del individuo sobre sí mismo con el objeto de cambiar sus modos de vida en un sentido anárquico: "No consideramos al naturismo como una simple cuestión de higiene y alimentación, sino como un género de vida que hace cambiar las ideas morales, y el concepto social..." Para ello -sostiene en otra parte-, es preciso que cada anarquista afirme el "el imperio sobre sí mismo" ajustando cada uno de sus actos a sus ideas, aprendiendo a diferenciar aquello que lo hace libre de las ataduras que lo sujetan a una cultura artificial e impuesta, y propiciando, en la medida de sus posibilidades, un retorno a la naturaleza. ${ }^{68}$ Esta tarea no es una que pueda realizarse siguiendo una serie de procedimientos de conducta prefijados de antemano por sistema doctrinal alguno, sino que requiere de un examen individual basado en la auto-educación, así como de una disposición ética a la revolución interior capaz de reformar cada ámbito de la vida.

\section{Palabras finales}

A lo largo del artículo, procuré exponer el modo particular en que un militante en cierto modo ignorado por los trabajos acerca de la historia del movimiento libertario en Buenos Aires concibe el anarquismo como una reflexión permanente sobre sus propias conductas y un medio para la transformación ética de sí mismo. Habituado a formas de la militancia tanto menos espectaculares cuanto más grises y meticulosas que los atentados violentos y la participación en huelgas generales, el tipo de anarquismo que practica y difunde Costa-Iscar parece no haber sido lo suficientemente estridente como para ganar la atención de los historiadores. Asimismo, la imagen que éstos construyen de las experiencias anarcoindividualistas de las primeras décadas del siglo XX -en gran parte tributaria del modo en que varios militantes del período, proclives a la organización e inmersos en la polémica con los individualistas, se

\footnotetext{
${ }^{66}$ Costa-Iscar, "El Naturismo y el problema humano. Gran conferencia-controversia", La Protesta, año XXVI, n 4390,4 de mayo de 1923.

67 Argos, Luis, "El naturismo y el problema humano", La Protesta, año XXVI, n 4401, 17 de mayo de 1923.

${ }^{68}$ Costa-Iscar, Manuel, Crítica y concepto libertario del naturismo, Buenos Aires, Bautista Fueyo, 1923, p. 27 y 24.
} 
refieren a estos últimos- no permite del todo comprender la existencia de preocupaciones y sensibilidades como aquellas que expresa el autor a cuyo pensamiento está dedicado este trabajo.

En este sentido, considero que el apoyo en la perspectiva teórica foucaulteana acerca de las tecnologías del yo permite iluminar unas formas particulares de ejercicio del anarquismo que tiene a la "realización individual", la "revolución interior" y el "imperio sobre sí mismo" -como sostiene, en distintos momentos y entre otras expresiones similares, el propio Costa-Iscar- entre sus más preciados propósitos no como subterfugio para eludir, sino en tanto camino ineludible para avanzar hacia la transformación social. Se trata ésta de una forma de la militancia comprometida con el trabajo ético de sí en cuanto modo de darse a sí mismo un estilo de vida insumiso a los imperativos sociales tanto como a las costumbres sacrificiales que -a pesar de su característico ateísmo y constantes diatribas contra la religión- expresan ciertas figuras emblemáticas del ideario ácrata. Este trabajo ético no se circunscribe a un determinado ámbito de aplicación, sino que considera indispensable la reflexión sobre un conjunto diverso de prácticas, así como el ensayo de formas alternativas para cada una de las instituciones que las emplazan. Si es posible comprender la reflexión crítica sobre las prácticas instituidas $-\mathrm{O}$, si se quiere, el método de auto-educación que Costa-Iscar propone en tanto modo de cuestionamiento de la verdad sobre la que se funda la autoridad- como un método anarquista basado en el principio de no legitimidad intrínseca del poder, el ensayo consigo mismo para distintos ámbitos de la vida de formas alternativas de existencia podría interpretarse como esas luchas transversales e inmediatas a las que Foucault llama luchas anarquistas.

Antes de finalizar, creo pertinente realizar dos últimas aclaraciones a modo de precaución. Por un lado, si el tipo de individualismo practicado por Costa-Iscar pareciera prestarse, sin mayores dificultades, a un análisis centrado en las prácticas de sí, esto no implica que otras formas de ejercicio de la militancia libertaria carezcan de instancias de reflexión ética en tanto forma de subjetivación moral. Las propias figuras del mártir y el revolucionario sostenidas por el ideario anarquista, contra las cuales nuestro autor se dispone a tomar distancia, podrían muy bien ser analizadas siguiendo esta misma perspectiva, por medio de la cual se lograrían precisar prácticas y relaciones de sí consigo mismo distintas a las aquí tratadas. Por otro lado, más allá de las singulares y, en ocasiones, inflexibles posiciones asumidas Costa-Iscar, éstas no debieran ser pensadas como meras excentricidades de un pensamiento discordante. Más bien, su sola presencia en la prensa libertaria nos invita a reflexionar volviendo al inicio de este trabajo- acerca de la complejidad del anarquismo en tanto movimiento capaz de albergar y poner en conexión múltiples experiencias de militancia.

\section{Bibliografía citada}

Abad de Santillán, Diego, El movimiento anarquista en la Argentina, Buenos Aires, Editorial Argonauta, 1930.

Acha, José María, Memorias de un anarquista, Biblioteca Anarquista del Cerro, Montevideo, s/f.

Albornoz, Martín, "Eduardo Gilimón y la obsesión por la propaganda", Gilimón, Eduardo, Hechos y comentarios. Y otros escritos: el anarquismo en Buenos Aires: 1890-1910, Buenos Aires, Terramar, 2011, p. 9.

Albornoz, Martín, "Los encuentros de controversia entre anarquistas y socialistas (1890-1902)", Bruno, Paula (Dir.), Sociabilidades y vida cultural. Buenos Aires, 1860-1930, Buenos Aires, Universidad de Quilmes, 2014, pp. 187-218.

Albornoz, Martín, "Los atentados anarquistas", Tonkonoff, Sergio et. al., Violencia y cultura: reflexiones contemporáneas sobre Argentina, Buenos Aires, CLACSO, 2014, pp. 31-47.

Álvarez Junco, José, La ideología politica del anarquismo español (1868-1910), Madrid, Siglo XXI de España Editores, 1976.

Álvarez Junco, José, “Los dos anarquismos”, Cuadernos de Ruedo Ibérico, segunda época, n 55-57, enerojunio de 1977, pp. 139-156. 
Anapios, Luciana, "La ciudad de las bombas. El anarquismo y la 'propaganda por el hecho' en la Buenos Aires de los años veinte", Boletin del Instituto de Historia Argentina y Americana "Dr. Emilio Ravignani", tercera serie, $\mathrm{n}^{\circ}$ 39, segundo semestre de 2013, pp. 42-75.

Anapios, Luciana, "Prensa y estrategias editoriales del movimiento anarquista en la Argentina de entreguerras", Anuario del Instituto de Historia Argentina, 16(2), e025, 2016. Disponible en: http://www.anuarioiha.fahce.unlp.edu.ar/article/view/IHAe025. Consultado el 1 de marzo de 1919.

Anónimo, Folletos anarquistas en Buenos Aires: publicaciones de los grupos La Questione Sociale y La Expropiación, Buenos Aires, Biblioteca Nacional, 2015.

Ansolabehere, Pablo, Literatura y anarquismo en Argentina: 1879-1919, Rosario, Beatriz Viterbo, 2011.

Barrancos, Dora, Anarquismo, educación y costumbres en la Argentina de principios de siglo, Buenos Aires, Editorial Contrapunto, 1990.

Bayer, Osvaldo, Severino Di Giovanni, Buenos Aires, Booket, 2006.

Bayer, Osvaldo, Los anarquistas expropiadores, Buenos Aires, Booket, 2008.

Campo, Hugo del, Los anarquistas, Buenos Aires, Centro Editor de América Latina, 1971.Domínguez, Lucas, "Un itinerario por los proyectos editoriales del anarquismo en Argentina: cambios, maniobras y permanencias”, Izquierdas, 33, mayo 2017, pp. 21-41.

Chignola, Sandro, Foucault más allá de Foucault: una politica de la filosofía, Trad. Fernando Venturi, Buenos Aires, Cactus, 2018.

Costa-Iscar, Manuel, Crítica y concepto libertario del naturismo, Buenos Aires, Bautista Fueyo, 1923.

Cubero Izquierdo, María Carmen, La pérdida del pudor. El naturismo libertario español (1900-1936), Madrid, LaMalatesta Editorial, 2015.

Di Stefano, Mariana, El lector libertario: prácticas e ideologías lectoras del anarquismo argentino: 1898-1915, Buenos Aires, Eudeba, 2013.

Diez, Xavier, El anarquismo individualista en España (1923-1938), Barcelona, Virus Editorial, 2007.

Doeswijk, Andreas L., Los anarco-bocheviques rioplatenses 1917-1930, Buenos Aires, CeDInCI Editores, 2013.

Fernández Cordero, Laura, Amor y anarquismo: Experiencias pioneras que pensaron y ejercieron la libertad sexual, Buenos Aires, Siglo XXI Editores, 2017.

Ferrer, Christian, "Átomos sueltos. El 'cuidado de sí' entre los anarquistas a comienzos del siglo XX", Abraham, Tomás (comp.), El último Foucault, Buenos Aires, Sudamericana, 2003, p. 239-262.

Foucault, Michel. "El sujeto y el poder", Trad. de Rogelio C. Paredes, Dreyfus, Hubert L. y Rabinow, Paul, Michel Foucault: más allá del estructuralismo y la hermenéutica, Buenos Aires, Nueva Visión, 2001, pp. 241-259.

Foucault, Michel, El coraje de la verdad: el gobierno de síy de los otros II. Curso en el College de France (19831984), Traducción de Horacio Pons, Buenos Aires, Fondo de Cultura Económica, 2010.

Foucault, Michel, Historia de la sexualidad II. El uso de los placeres, Trad. de Solet Martí, Buenos Aires, Siglo XXI, 2011.

Foucault, Michel, Del gobierno de los vivos: Curso en el Collège de France: 1979-1980, Trad. de Horacio Pons, Buenos Aires: FCE, 2014.

Gilimón, Eduardo, Hechos y comentarios. Y otros escritos: el anarquismo en Buenos Aires: 1890-1910, Buenos Aires, Terramar, 2011.

Girón Sierra, Álvaro, En la mesa con Darwin. Evolución y revolución en el movimiento libertario en España (18691914), Madrid, Consejo Superior de Investigaciones Científicas, 2005.

Iñíguez, Miguel, Esbozo de una enciclopedia histórica del anarquismo español, Madrid, Fundación de Estudios Libertarios Anselmo Lorenzo, 2001.

Joll, James, Los anarquistas, Barcelona, Ediciones Grijalbo, 1968.

Karush, Matthew B., Cultura de clase. Radio y cine en la creación de una Argentina dividida (1920-1946), Buenos Aires, Ariel, 2013. 
Ledesma Prietto, Nadia, "La revolución sexual de nuestro tiempo": el discurso médico anarquista sobre el control de la natalidad, la maternidad y el placer sexual. Argentina, 1931-1951, Buenos Aires, Biblos, 2016.

Litvak, Lily, Musa libertaria: arte, literatura y vida cultural del anarquismo español (1880-1913), Madrid, Fundación de Estudios Libertarios Anselmo Lorenzo, 2001.

Masjuan, Eduard, La ecología humana del anarquismo ibérico: urbanismo "orgánico" o ecológico, neomalthusianismo y naturismo social, Barcelona, Icaria, 2000.

Morey, Miguel, “Introducción”, Foucault, Michel, Tecnologías del yo, Buenos Aires, Paidós, 2008, pp. 944.

Nieto, Agustín, "Notas críticas en torno al sentido común historiográfico sobre 'el anarquismo argentino"', A Contracorriente, vol. 7, n 3, primavera de 2010, pp. 219-248.

Oved, Iaacov, El anarquismo y el movimiento obrero en Argentina, México, Siglo XXI Editores, 1978.

Roselló, Josep Maria, La vuelta a la naturaleza. El pensamiento naturista hispano (1890-2000): naturismo libertario, trofología, vegetarismo naturita, vegetarismo social y librecultura, Barcelona, Virus Editorial, 2003.

Saítta, Sylvia, Regueros de tinta. El diario Crítica en la década de 1920, Buenos Aires, Sudamerica, 1998.

Sarlo, Beatriz, Una modernidad periférica: Buenos Aires 1920-1930, Buenos Aires, Nueva Visión, 2003.

Schürmann, Reiner, "De la constitución de uno mismo como sujeto anárquico", Traducción de Alan Cruz e Ilya Semo Bechet, Fractal, $\mathrm{n}^{\circ}$ 75, enero-abril de 2015. Disponible en: https://www.mxfractal.org/articulos/RevistaFractal75ReinerSchurmann.php?fbclid=IwAR0VQS2SBY iubWSBYiubWWgT5BYeSdG_hUpFxRy9TiL4VqlBuB-cjitxvo. Consultado el 6 de marzo de 2019.

Stavisky, Sebastián, "Médicos de sí mismos. Medicina naturista, revolución social y éxodo de la ciudad en el anarquismo de Buenos Aires a comienzos del siglo XX", ecopolítica, no 16, septiembre-diciembre de 2016, pp. 2-25. Disponible en https://revistas.pucsp.br/index.php/ecopolitica/article/view/34166. Consultado el 12 de enero de 2019.

Stavisky, Sebastián, "La primera víctima del movimiento obrero. El discurso anarquista sobre la muerte en los albores del siglo XX en Argentina", Revista Conflicto Social, año 10, n 18, julio-diciembre de 2017, pp. 168-195. Disponible en https://publicaciones.sociales.uba.ar/index.php/CS/article/view/2657/0. Consultado el 12 de enero de 2019.

Stavisky, Sebastián, "Crítica al humanismo y ética de sí en Foucault y Stirner", Revista de Humanidades, n” 40, julio-diciembre de 2019, en prensa.

Suriano, Juan, Anarquistas: cultura y politica libertaria en Buenos Aires, 1890-1910, Buenos Aires, Manantial, 2008.

Suriano, Juan y Anapios, Luciana, "Anarquistas en las calles de Buenos Aires (1890-1930)", Lobato, Mirta Zaida (editora), Buenos Aires: manifestaciones, fiestas y rituales en el siglo XX, Buenos Aires, Biblos, 2011, pp. 77-100.

Zaragoza Ruvira, Gonzalo "Aproximación al anarquismo americano: el caso argentino", Estudios: Revista de historia moderna, $\mathrm{n}^{\circ}$ 5, 1976, pp. 173-185.

Zaragoza Ruvira, Gonzalo, Anarquismo argentino (1876-1902), Madrid, Ediciones de la Torre, 1996.

\section{Fuentes periódicas}

Claridad, Buenos Aires, 1934.

La Antorcha, Buenos Aires, 1921.

La Protesta, Buenos Aires, 1909-1928.

La Protesta Humana, Buenos Aires, 1901.

La Protesta. Suplemento Quincenal, Buenos Aires, 1927.

La Protesta. Suplemento Semanal, Buenos Aires, 1922-1923.

Nervio, Buenos Aires, 1931.

Superación, Buenos Aires, 1925.

Tierra y Libertad, Barcelona, 1910-1914. 